\title{
FORESTRY LAND USE OPTIMIZATION ON THE MOUNTAINOUS TERRITORY IN UKRAINIAN CARPATHIANS (TERLO COMMUNITY IN STARY SAMBIR DISTRICT IN LVIV REGION)
}

\author{
Iryna Koynova, Maksym Terletskyi \\ Ivan Franko National University of Lviv, \\ P. Doroshenko Str., 41, UA - 79000 Lviv, Ukraine
}

\begin{abstract}
In this research, characteristics of the forestry land use within a typical mountainous territory of the Terlo community were explained. Local economic and natural processes were characterized and connections between forestry land use and sustainable development of all community were found. Forestry land use enterprises backgrounds were discovered. Negative aspects of two different forestry administration systems were found and main causes of modern states of the forest stands were explained. Modern forest stands were compared with optimal forest stand characteristics, recommended by the FORZA project for Ukrainian Carpathians. A forest stand structure which characterized by forest species, an age structure, a tree canopy, a number of forest tiers within the smallest part of forestry enterprises were analyzed, using a map visualization tools. Based on the results of this research, optimization measures for sustainable forestry development were recommended.

Key words: forestry land use, forests of exploitation, nature protected forests, sustainable forestry development.
\end{abstract}

Forest is a main natural resource and it is a basis for the mountain rural development in the Ukrainian Carpathians. There are many functions, which forest plays. Economical, ecological (regulating of water flow, water and soil erosion) as examples. Therefore, forestry land-use plays a main role in sustainable mountain rural development. The analysis of modern state of forestry system will provide optimization and rational use of the forest resources. Terlo community land are model lands, they represent Ukrainian Carpathians region at all according to their land structure and economic activities. More than a half part of the community lands are covered by forests and forestry is a main local activity.

A main goal in this research was to analyze modern state of forest land-use and to propose forestry optimization measures on the territory of Terlo community.

An object of study was forest fund lands within a Terlo community territory in Stary Sambir district in Lviv region.

A subject of study was the modern state features of forestry land-use and there conformity to the "natural forestry" features.

Many national researchers discussed problems of the forestry land-use. Ukrainian scholars S. Hensiruk (1971), S. Stoyko, I. Koynova (2014) were developed strategies of a complex forestry practices and optimization technologies [1,4]. According to Lviv national university professor Z. Pankiv, forestry land-use is a type of land-use (covered by forests and not covered by forests [but those relating to the forest fund]), used by forestry enterprises and Ukrainian citizens, which provide ecological, economic, social and other services and forest goods (fiber, technical, pharmaceutical, others). The main forms of forestry land-use are

(C) Koynova I., Terletskyi M., 2015 
an exploitation land-use, a soil protection and a water protection land-use, and a recreational land-use [3].

The modern state analyses of forestry land-use on the territory of Terlo community based on the criteria, which characterized the modern state of forest productivity and stability. These criteria are main indicators of forestry land-use and forestry as an economic branch at all. Productivity and stability criteria were created during a FORZA project development in Ukrainian Carpathians. Features of forest stand, such as an age structure, vertical and horizontal forest features were taken into an account.

A data from a local forest taxation description were compared with optimal criteria (4 of 10 description features) recommended to the territory where Terlo community is, which were also developed during the FORZA project [2] (table 1). The results gave an option to analyze forestry practices on the territory of community, precisely results of these practices. Moreover, recommendations to the forestry practices optimization, based on the "natural forestry" practices were created.

"Natural forestry" or natural preserved forestry based on the forestry practices, which characterized by six principles [2]:

- continuously existed forest cover;

- stability of water and soil preservation;

- climate regulating, recreational, sanitary hygienic and other useful forest features stability;

- biodiversity preservation;

- natural uneven forest structure restoration;

- natural logging technologies are used.

Table 1

Optimization criteria for beech (Fagus sylvatica) and fir-tree (Abies alba) forest stands [2]

\begin{tabular}{|l|l|l|}
\hline \multicolumn{1}{|c|}{$\begin{array}{c}\text { Description features } \\
\text { (4 of 10) }\end{array}$} & \multicolumn{1}{|c|}{ Natural preserved forests } \\
\hline $\begin{array}{l}\text { Composition of forest } \\
\text { stand, \% }\end{array}$ & $\begin{array}{l}\text { Fir-tree }-60-70 \\
\text { Beech }-20-30 \\
\text { Sycamore (Acer pseudoplatanus) }-5-10 \\
\text { Spruce (Picea abies) }-2-5\end{array}$ & $\begin{array}{l}\text { Fir-tree }-70-80 \\
\text { Beech }-10-20 \\
\text { Sycamore }-5-10 \\
\text { Spruce - 2-5 }\end{array}$ \\
\hline Age structure & $\begin{array}{l}\text { Absolutely different ages, trees are vital } \\
\text { in three tiers }\end{array}$ & $\begin{array}{l}\text { Absolutely different ages, trees } \\
\text { are vital in three tiers }\end{array}$ \\
\hline Vertical structure & Three tiers & Two tiers \\
\hline $\begin{array}{l}\text { Horizontal structure } \\
\text { tree canopy) }\end{array}$ & Min tree canopy $-0,7-0,8$ & Min tree canopy $-0,7-0,8$ \\
\hline
\end{tabular}

Terlo community territory is located in the Upper Beskydy region in the Ukrainian Carpathians. Low mountain ranges are divided by riverbeds. Average heights change from $365 \mathrm{~m}$ to $740 \mathrm{~m}$. Climate is temperate continental with average temperature in July $-18^{\circ} \mathrm{C}$ and an average temperature in January $--4{ }^{\circ} \mathrm{C}$. On the lowest parts of these riverbeds village Terlo and Libuchova are situated with the total population more than 1400 people. Last decades there are many catastrophic floods on rivers. The main causes of it are bad natural resource management, especially non rational forestry land use.

Forestry land-use on the territory of Terlo community is conducting on the forest fund lands. There are two forms of forestry land use: exploitation (on the territory where 
exploitation forest are spread) and water preserved (on the lands, where water preserved zones were created). There are two enterprises which use forest lands within Terlo community territory: "Stary Sambir state forestry and hunting enterprise" ("Stary Sambir SFHE") and the regional communal forestry enterprise "Halsillis" which uses former agriculture forests nowadays.

A total forest fund lands area within Terlo community is 3395,16 ha. It is approximately $80 \%$ from the whole community area. $55,13 \%$ (1871,78 ha) of the forest fund lands belongs to "Stary Sambir SFHE" and other 1523,38 ha or 44,87 \% belongs to "Halsillis" (table 2).

Table 2

Forest fund lands within Terlo community territory

\begin{tabular}{|c|c|c|}
\hline Forestry land-users & Land area, ha & Percent in forest fund \\
\hline "Stary Sambir SFHE" & 1871,78 & 55,13 \\
\hline "Halsillis" & 1523,38 & 44,87 \\
\hline
\end{tabular}

Forest lands which are under the rule of "Stary Sambir SFHE" are divided between two smaller enterprise divisions: Terlo forestry and Stariava forestry enterprises. Those forest lands, which belong to Terlo forestry enterprise, are a part of an economic zone in "Upper Dniester Beskydy" Regional Landscape Park. The biggest part of forest lands in "Stary Sambir SFHE" are forests of exploitation $(81,25 \%)$, which means that fiber is a main forest good on these lands. Felled forests in 2015 year were covered 93,93 ha (including 88,37 ha of them, created in 2015). Creating such a huge scaled cutting area on the Strviazh riverbed was done without any natural preserved events.

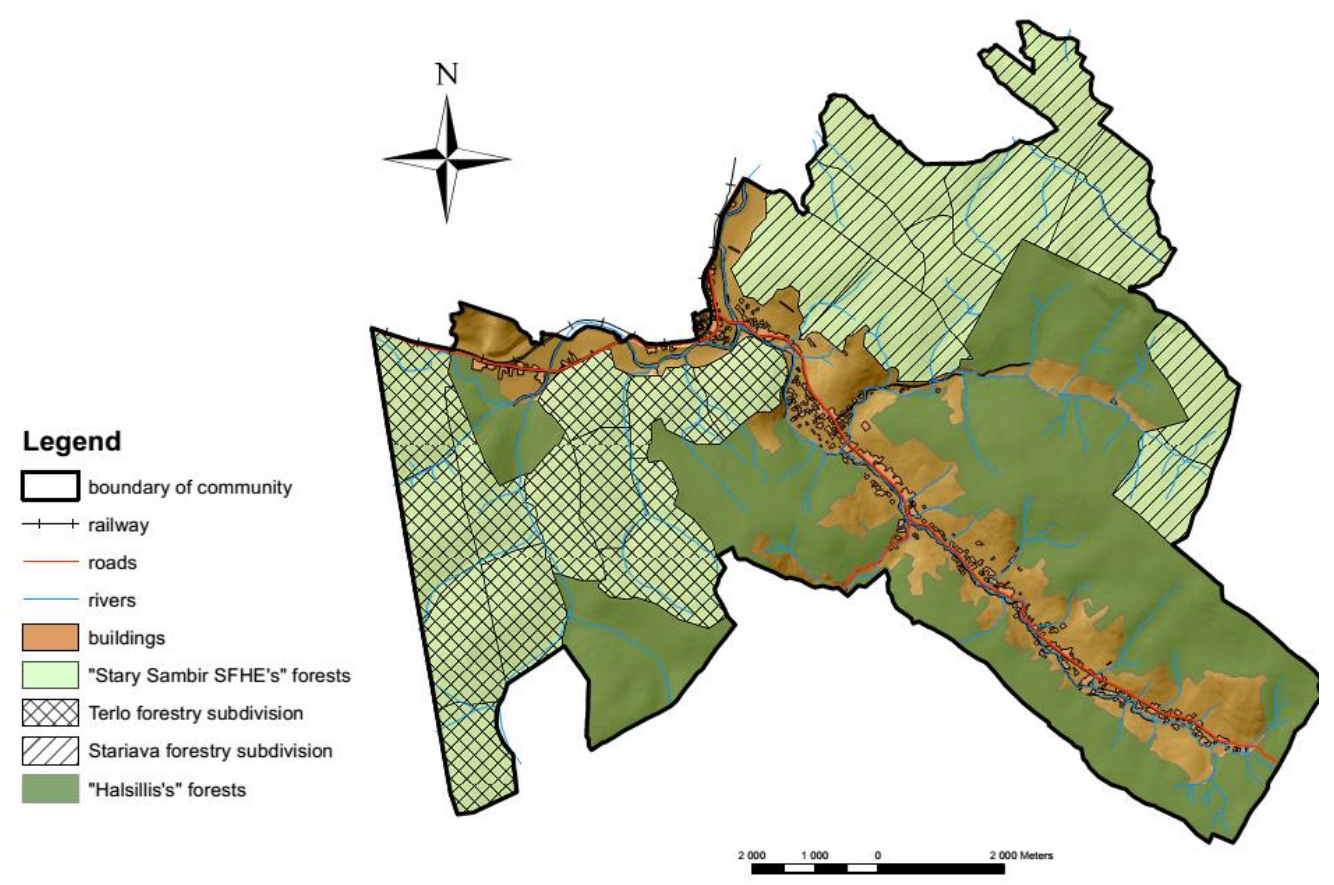

Fig. 1. Forestry land use within the territory of Terlo community 
As a result, frequent floods with catastrophic character were observed during last years. Forest massifs accumulate atmospheric water and their descending during last decades cause catastrophic floods and water erosion on rivers in the Carpathian region at all.

The area of bank protected forests is 70,9 ha (4\%). These forest lands are located within water preserved zones. However, not all water preserved zones within forest fund lands are covered by forests.

Reforestation on the territory of "Stary Sambir forestry and hunting enterprise" within Terlo community territory is doing on the 83,64 ha lands. Restoration processes are mainly natural, without human impact on it. Reforestation areas are covered by the fir-tree and beech forest stands without closed canopy.

There are 66 ha of lands within forest fund, which are used as bio-lawns, where feeders for wild animals were created. The biggest part of them is located within the Terlo forestry enterprise, because it is a territory of the regional landscape park.

The forest lands, which are located near the Ukrainian-Polish border, cover $2 \%$ of all "Stary Sambir SFHE" lands. A chopping is a main human activity there, because border services have to observe a boundary line daily.

Table 3

Forestry land-use features on the territory of "Stary Sambir SFHE" within Terlo community area

\begin{tabular}{|c|c|c|c|c|c|c|}
\hline \multirow[t]{2}{*}{ Type of forestry land-use } & \multicolumn{2}{|c|}{$\begin{array}{c}\text { Stariava forestry } \\
\text { enterprise }\end{array}$} & \multicolumn{2}{|c|}{$\begin{array}{c}\text { Terlo forestry } \\
\text { enterprise }\end{array}$} & \multicolumn{2}{|c|}{$\begin{array}{c}\text { Total StarySambir } \\
\text { SFHE lands } \\
\end{array}$} \\
\hline & area, ha & $\%$ & area, ha & $\%$ & area, ha & $\%$ \\
\hline bank prevented forest lands & 33,40 & 4,10 & 37,50 & 3,56 & 70,90 & 3,79 \\
\hline bio-lawns & 13,38 & 1,64 & 52,16 & 4,95 & 65,54 & 3,51 \\
\hline felled tree area (before 2015) & 4,51 & 0,55 & 1,05 & 0,10 & 5,56 & 0,30 \\
\hline exploitation forests & 635,49 & 77,93 & 883,11 & 83,82 & 1518,60 & 81,25 \\
\hline reforestation area & 40,36 & 4,95 & 43,28 & 4,11 & 83,64 & 4,47 \\
\hline felled tree area (during 2015) & 88,37 & 10,84 & 0,00 & 0,00 & 88,37 & 4,73 \\
\hline forest lands along state boundary & 0,00 & 0,00 & 36,46 & 3,46 & 36,46 & 1,95 \\
\hline
\end{tabular}

The species structure of the forest stands under the rule of "Stary Sambir SFHE" is characterized by Abies alba, Fagus sylvatica, Acer pseudoplatanus, Picea abies spreading. These species are dominant but also there are Pinus sylvestris, Alnus incana, Larix decidua, Prunus avium and others.

Comparing a composition of the forest stands within the smallest parts of forestry enterprises called "vydils" with optimal features for fir-tree and beech forests (see table 1), a huge discrepancy were found. There are no one vydil within Terlo community with optimal forest stand characteristics. Only percentages of the individual tree species were optimal among some vydils. 60-70\% of Abies alba per forest stand are presented in 50 vydils within the natural preserved forests (bank preserved forests) and the forests of exploitation. A total area of these forest stands is 203,73 ha (10,89\% of the enterprise's forest lands). A Fagus sylvatica is presenting with an optimal percentage in 93 vydils, with a total area of 358,34 ha $(19,14 \%)$. An Acer pseudoplatanus percentage is optimal in 72 vydils, which are covering 432,44 ha $(23,1 \%)$ of the "Stary Sambir state forestry and hunting enterprise" area. And there are 48 vydils $(254,46$ ha and $13,6 \%)$ with an optimal percentage of a Picea abies spreading. 
Therefore, a forest stand structure, according to the species percentage, does not meet the standard indicators, recommended for the natural forestry practices. It causes a forest stability decreasing and a pest spreading increase. An active human impact, on the forest ecosystems, will be necessary in early future.

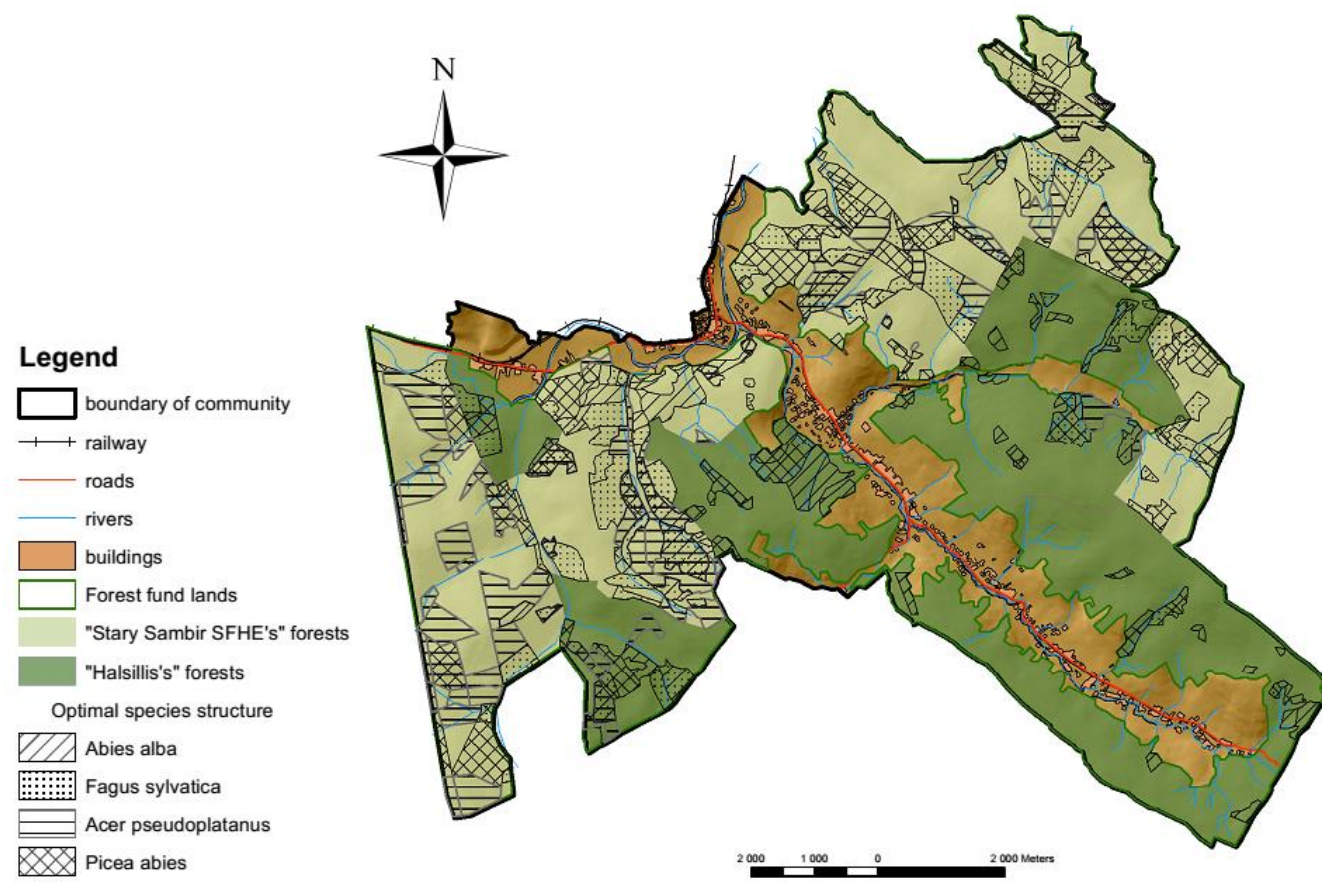

Fig. 2. Optimal species percentage within vydils within the territory of Terlo community

An age structure of the forests stands within the "Stary Sambir SFHE" lands is characterized by the coeval forests spreading. Their area is 1230,13 ha or $65,67 \%$ of enterprise's lands within a Terlo community. It is caused by the felled forest areas creating and planting new trees on these empty lands. Very often local people cut the ripe trees illegally, which caused a unification of forest stands and the coeval trees leaving. For the forest stability sustention, a different-ages structure is optimal. However, only just a third part of forest stands within the forestry enterprise is characterized by the different-age structure. A total area of a different-age forest stands is 24,77 ha. These forest stands are located mainly on the lands near a boundary line, which is a less human changed territory.

A number of forest tiers characterizes a vertical structure of the forest stands within "Stary Sambir SFHE". Today this characteristic is not optimal on the biggest part of these forest stands. Only forests on the area of 161,01 ha have two tiers and only one vydil has three tiers. Having a one tier in their vertical structure, forest becomes less stable for external features and their ecological functions decrease. These forest stands do not absorb moisture and delay rain power. It causes an erosion processes developing and a soil fertility decreasing. More tiers in forests help to save a biodiversity on higher level, which is one of a main aspect of the sustainable forestry land-use. 
A horizontal structure of the forest stands is optimal and a forest stand canopy is equal more than 0,7 on the area of 1171,07 ha $(62,56 \%)$ within the "Stary Sambir SFHE" lands. Less than 0,7 canopy is characterized for the lands on the area of 517 ha. Different monoculture forest stands are characterized by lower canopy. Other reason of this is an illegal cutting. While canopy is in a good connection with a forest stands composition and a number of forest tiers inside these forest stands, it is caused a soil erosion processes. So, as higher is tree canopy as less erosion processes are developed on the lands, covered by the forest vegetation. Moreover, as lower erosion process is developed, as more fertile are soils, which are a fundament of forest being. In accordance, our intervention into this natural forest system circle causes a self-healing and self-regulation ability decreasing.

Forestry management on the lands, which are under the regional communal forestry enterprise "Halsillis", was arranged very irrational during the last century. Because of the being under the agriculture communal enterprise's rule, they were cut for fiber resource without a proper reforestation. An extensive agriculture caused the agriculture fields increasing on the forest lands. Because of the fast growing, a Pinus sulvestris were used as a main planting culture in the past. Modern forestry practices are characterized by cutting this culture and planting natural forests - ones that are more valuable and had been on these lands before.

Modern forestry land-use on the lands under the "Halsillis" rule (table 4) is characterized by the forest of exploitation predominance $-996,06$ ha $(65,38 \%)$. An area of preservation forests is 114,29 ha $(0,17 \%)$, approximately 2 ha is covered by a felled forest area. And 377,18 ha $(24,76 \%)$ of forest lands are not covered by a forest vegetation - there are territories of the former agriculture fields. Today these areas are characterized by a Pinus sylvestris self-sowing.

Table 4

Forestry land-use structure on the territory of "Halsillis" within a Terlo community area

\begin{tabular}{|l|r|r|}
\hline \multicolumn{1}{|c|}{ Forestry land-use types } & area, ha & \multicolumn{1}{c|}{$\%$} \\
\hline Forests of exploitation & 996,06 & 65,38 \\
\hline Bank reserved forests & 114,29 & 7,50 \\
\hline Bio-lawns & 2,64 & 0,17 \\
\hline Felled forests & 1,96 & 0,13 \\
\hline Reforestation areas & 31,25 & 2,05 \\
\hline Forest lands without forest vegetation & 377,18 & 24,76 \\
\hline
\end{tabular}

Within a forest stand structure of the "Halsillis" forests, the Spruce and Pine forests are predominant. However, there are some sections where Larix decudia, Betula pendula, Alnus incana and Salix alba are prevailed (see table 5).

A Picea abies is spreading on the preserved territories. These lands are located on the left and right bank slopes of the river Libuchivka, the left bank slopes of the river Smerechanka and the upper lands of the river Rudavka. A main part of the forest of exploitation are pine forest with a Picea abies monoculture as a dominate species. An Alnus incana dominates in the lowest parts of the riverbeds. In particular, the biggest areal of the Alnus incana spreading is located in the river Rudavka mouth. This place is also characterized by a Salix alba spreading.

Fagus sylvatica, Acer pseudoplatanus and Picea abies are spreading as the non-dominant species among Abies alba, Pinus sylvestris and Alnus incana forest stands. 
Forest stands fraction according to the predominant species on the "Halsillis" lands within a Terlo community, $\%$

\begin{tabular}{|c|c|c|c|c|c|c|c|c|c|}
\hline $\begin{array}{c}\text { Namber } \\
\text { of the } \\
\text { forestry } \\
\text { enterprise } \\
\text { division }\end{array}$ & $\begin{array}{c}\text { Abies } \\
\text { alba }\end{array}$ & $\begin{array}{c}\text { Fagus } \\
\text { sylvatica }\end{array}$ & $\begin{array}{c}\text { Acer } \\
\text { pseudo- } \\
\text { platanus }\end{array}$ & $\begin{array}{c}\text { Picea } \\
\text { abies }\end{array}$ & $\begin{array}{c}\text { Alnus } \\
\text { incana }\end{array}$ & $\begin{array}{c}\text { Salix } \\
\text { alba }\end{array}$ & $\begin{array}{c}\text { Picea } \\
\text { abies }\end{array}$ & $\begin{array}{c}\text { Betulla } \\
\text { pendula }\end{array}$ & $\begin{array}{c}\text { Larix } \\
\text { decudia }\end{array}$ \\
\hline 9 & 37,41 & - & - & - & 49,64 & 12,95 & - & - & - \\
\hline 10 & 30,10 & - & - & - & - & - & 69,90 & - & - \\
\hline 11 & 16,40 & - & - & - & 10,41 & - & 72,39 & 0,45 & 0,35 \\
\hline 12 & 30,05 & - & - & - & 11,13 & - & 54,85 & 3,98 & - \\
\hline 13 & 32,85 & - & - & - & - & - & 61,43 & - & - \\
\hline 14 & 68,87 & - & - & - & 1,30 & - & 29,83 & - & - \\
\hline 15 & 41,58 & - & - & - & 3,92 & - & 54,50 & - & - \\
\hline 16 & 67,43 & - & - & - & - & - & 32,57 & - & - \\
\hline 17 & 50,51 & - & - & - & - & - & 49,49 & - & - \\
\hline 18 & 43,84 & - & - & - & 23,17 & - & 30,79 & 2,20 & - \\
\hline
\end{tabular}

Comparing a modern state of the forest stands under the "Halsillis" rule within Terlo community lands, the 116,51 ha of forests with an optimal fractions of the Abies alba were found. A Fagus sylvatica's optimal fraction is on the 90,1 ha of forests. An Acer pseudoplatanus is characterized by an optimal fraction in ninth vydils with a total area of 35,08 ha. An optimal fraction of the Picea abies could be found on the 98,06 ha of forest lands within a "Halsillis" enterprise.

An age structure of the forest stands within "Halsillis" lands is characterized by the coeval forests spreading. Their total area is 937,94 ha $(81,83 \%)$. The different aged forests covering an area of 160,71 ha $(14,02 \%)$.

A vertical structure of forest stands is characterized by the one tier structure. Two or three tiers are presented in the forest stands where an Abies alba predominate.

A tree canopy for the forest stands of "Halsillis" is changing between 0,3-0,9. A main part of the forest stands are not optimal, because of a tree canopy under 0,7 presenting. Only within the forest stands, where an Abies alba, a Fagus sylvatica, an Acer pseudoplatanus and other leaf species are spreading, the tree canopy is higher than 0,7 and these forest stands are optimal due to this characteristic.

In total, a forestry land-use within a Terlo community is characterized by a heterogeneity, which is caused by a different subordination of forest lands, a different history of forest lands use and a modern state of forest stands heterogeneity. Those forests, which are under the "Stary Sambir SFHE" are characterized as more optimal according to a rational use of forest lands and a better forestry in last century. However, a modern forestry land use within the "Stary Sambir SFHE" is not going to be as the natural forestry principles are dictating today. The felled forest areas are creating, the monoculture planting practices are conducting. It causes the coeval and the one-tier forest stands spreading. To achieve an optimal forest stands structure and a natural forestry land-use, an overhaul of forest stands should be conduct on the way of a selective logging use above the species, fraction of which are more than an optimal one. Moreover, a forest undergrowth development should be 
conduct with valuable forest species preservation and a different ages and many tiers forest stands formation.

Regional communal forestry enterprise "Halsillis" got a "revenue" from the Soviet Union - huge areas of a Pinus sylvestris spreading. This species is a weed for the natural ecosystems of a Terlo community territory. A forest stand structure is not optimal. Many vydils under the "Halsillis" rule are characterized by a Fagus sylvatica and an Acer pseudoplatanus missing, which do not allow them to be optimal. It causes a discrepancy in age, vertical and horizontal structure with optimal characteristics recommended for the natural forestry practices. Lands, which are not covered by forests, are characterized by a Pinus sylvestris self-seeding and valuable species oppression. Therefore, an absence of rational seed management will cause more areas of the Pinus sylvestris spreading and negative economic consequences will be in future. To optimize the forestry land use on the lands under the "Halsillis", the Pinus sylvestris forests should be cut and natural Fagus sylvatica and Abies alba forests should be create with the optimal age, horizontal and vertical structure.

Problems of forestry land use in Terlo community are typical for all mountainous regions in the Ukrainian Carpathians. The main causes of it are unthinkable and extensive economy during the Soviet times $\left(50^{\text {th }}-70^{\text {th }}\right.$ years of the XX century) and a professional management absence nowadays. Agriculture fields are located on the steep slopes, transport ruin the upper soil layer and lineal erosion is developing fast. But one of the main problems is a forestry land use: cutting trees on the steep slopes and transporting them in summer period destroy landscapes; different dynamic processes are developing on these destroyed lands. All these anthropogenic influences have a mirror negative effect today and will have bad consequences in the future. Providing modern technologies of forestry land use like a technology of selective cutting with preserving measures for nature, which was offered in FORZA project in the Ukrainian Carpathians. Better control of illegal cutting and total ban of cut the trees during a warm period, when soils are more prone to erosion will decrease erosion processes. Natural forestry practices on the community lands, where forest lands are covered more than $80 \%$ of all community area, should be a milestone of Terlo community sustainable development in future.

\section{СПИСОК ВИКОРИСТАНОЇ ЛІТЕРАТУРИ}

1. Генсирук С. А. Комплексное лесное хозяйство в горных условиях / С. А. Генсирук. - Москва : Лесная промышленность, 1971. - 248 с.

2. Наближене до природи лісівництво в Українських Карпатах / М. В. Чернявський, Р. Швіттер, Р. В. Ковалишин [та ін.]. - Львів : Піраміда, 2006. - 88 с.

3. Паньків 3. П. Еволюція землекористування в Україні : монографія / 3. П. Паньків. Львів : ЛНУ імені Івана Франка, 2012. - 188 с.

4. Стойко C. М. Антропогенна трансформація природних екосистем Українських Карпат та программа сталого розвитку / С. М. Стойко, І. Б. Койнова // Вісн. Львів. ун-ту. Сер. геогр. - 2014. - Вип. 45. - С. 49-63. 


\title{
REFERENCES
}

1. Gensiruk, S. A. (1971). Kompleksnoe lesnoe khoziaistvo v gornykh usloviiakh. Moskva: Lesnaia promyshlennost, 248 pp. (in Russian).

2. Cherniavskyi, M. V., Shvitter, R., Kovalyshyn, R. V., et al. (2006). Nablyzhene do pryrody lisivnytstvo v Ukrainskykh Karpatakh. Lviv: Piramida, 88 pp. (in Ukrainian).

3. Pankiv, Z. P. (2012). Evoliutsiia zemlekorystuvannia v Ukraini. Lviv: LNU imeni Ivana Franka, 188 pp. (in Ukrainian).

4. Stoyko, S. M., \& Koynova, I. B. (2014). Anthropogenic transformation of natural ecosystems of Ukrainian Carpathians and programme of sustainable development. Visnyk of the Lviv. University. Series Geography, 45, 49-63 (in Ukrainian).

Стаття: надійшла до редакиії 21.10.2015 доопрацьована 18.11.2015

прийнята до друку 03.12.2015

\section{ОПТИМІЗАЦІЯ ЛІСОКОРИСТУВАННЯ У ГІРСЬКИХ УМОВАХ УКРАЇНСЬКИХ КАРПАТ (НА ПРИКЛАДІ СЕЛА ТЕРЛО СТАРОСАМБІРСЬКОГО Р-НУ ЛЬВІВСЬКОЇ ОБЛ.)}

\author{
Ірина Койнова, Максим Терлецький
} Львівський національний університет імені Івана Франка,
вул. П. Дороченка, 41, 79000, м. Львів, Украӥна

\footnotetext{
Схарактеризовано особливості лісогосподарського землекористування на прикладі гірської території Терлівської сільської ради в межах Старосамбірського р-ну Львівської обл. Досліджено місцеві економічні й природні процеси та виявлено залежність між лісогосподарським землекористуванням і сталим розвитком території сільської ради у перспективі. Проаналізовано історичні особливості лісогосподарського землекористування. 3'ясовано негативні аспекти різних систем управління лісами в минулому та особливості сучасних станів деревостану. На підставі картографічної візуалізації проаналізовано сучасну структуру деревостанів, віковий склад, зімкнутість крон та кількість ярусів у межах найменших структурних одиниць лісогосподарських підприємств. Виконано порівняння цих показників із показниками оптимальних деревостанів, що були рекомендовані в рамках проекту FORZA для Українських Карпат, на засадах чого зроблено рекомендації щодо оптимізації вікового та породного складу лісів досліджуваної території.

Ключові слова: лісокористування, експлуатація лісів, охорона лісів, сталий розвиток лісів.
} 